\title{
Steringophorus merretti n. sp. (Digenea: Fellodistomidae) from the deep-sea fish Cataetyx laticeps Koefoed (Ophidiiformes: Bythitidae) from the Goban Spur, Northeastern Atlantic Ocean
}

\author{
Rodney A. Bray (iD) Andrea Waeschenbach
}

Received: 11 December 2019 / Accepted: 20 January 2020 /Published online: 3 June 2020

(C) The Author(s) 2020

\begin{abstract}
A new species of deep-sea digenean, Steringophorus merretti n. sp., is described from the bythitid fish Cataetyx laticeps in deep waters of the Goban Spur, Northeastern Atlantic. It is distinguishable from other described members of the genus by its tiny eggs and large cirrus-sac. A phylogenetic tree, based on $28 \mathrm{~S}$ rDNA sequences, indicates that this species is embedded within a clade of deep-sea species and is sister to the eurybathic species $S$. thulini Bray \& Gibson, 1980. Steringotrema robertpoulini PérezPonce de León, Anglade \& Randhawa, 2018 falls within the Steringophorus Odhner, 1905 clade. In view of this the morphological and biological characteristics of species of Steringophorus and Steringotrema are discussed.
\end{abstract}

\section{Introduction}

In 1999, we (Bray et al., 1999) published a phylogenetic tree exploring the possible deep-sea radiation of a group of fellodistomid digenean genera, mostly members of Steringophorus Odhner, 1905. All but one species was named. This unnamed species is described here from specimens from the same source as that sequenced in 1999. Several authors have used the named species in subsequent explorations of the fellodistomid phylogeny (Sun et al., 2014; Antar \& Gargouri, 2016; Wee et al., 2017a; Wee et al., 2017b; Cutmore et al., 2018; Pérez-Ponce de León et al., 2018), but only one (Cribb et al., 2014) has included the unnamed species. In describing and naming this species, we hope that the sequences obtained from this rare and difficult to obtain deep-sea digenean will be used by all subsequent workers on fellodistomid phylogeny.

\section{Materials and methods}

This article was registered in the Official Register of Zoological Nomenclature (ZooBank) as urn:lsid:zoobank.org:pub: 8B7C2615-C334-45A6-BF23-10A8A119F37D. This article was published as an Online First article on the online publication date shown on this page. The article should be cited by using the doi number. This is the Version of Record.

This article is part of the Topical Collection Digenea.

R. A. Bray $(\square) \cdot$ A. Waeschenbach

Department of Life Sciences, Natural History Museum,

Cromwell Road, London SW7 5BD, UK

e-mail: rab@nhm.ac.uk
The host specimens were caught aboard the RRS Challenger, Cruise 43/1994, at the Goban Spur. The Goban Spur is an area of relatively shallower water that forms the southern margin of the Porcupine Seabight, a deep-water oceanic basin located on the continental margin to the west of southern Ireland. The fish were caught using an OTSB (semi-balloon otter trawl) with a single warp and dissected as soon as 
possible after being brought aboard. The live digeneans were washed in saline and fixed in Berland's fluid for morphological study and 80\% ethanol for molecular study. Whole-mounts were stained with Mayer's paracarmine, cleared in beechwood creosote and mounted in Canada balsam. Measurements were made through a drawing tube on an Olympus BH-2 microscope, using a Digicad Plus digitising tablet and Carl Zeiss KS100 software adapted by Imaging Associates, and are quoted in micrometres. The following abbreviation is used: NHMUK, Natural History Museum, London, UK. The discussion of the hosts and distribution of Steringophorus and Steringotrema spp. is based on a database developed by $\mathrm{Dr}$ Thomas Cribb, at the University of Queensland, and maintained to date by RAB.

All 28S rDNA sequences used for this study were obtained from GenBank, although many were originally generated in our laboratory. Outgroup selection was informed by an unpublished $28 \mathrm{~S}$ rDNA tree topology obtained for the preparation of Littlewood et al. (2015). Sequences were aligned using MAFFT version $7.157 \mathrm{~b}$ (Katoh, 2008) with 1,000 cycles of iterative refinement and the genafpair algorithm. Ambiguously aligned positions were excluded by eye in Mesquite (Maddison \& Maddison, 2018). MrModeltest v.2.3 (Nylander, 2004) was used to select a model of sequence evolution using the Akaike Information Criterion. Bayesian inference was performed using MrBayes version 3.2.2 (Ronquist et al., 2012). Two parallel runs were performed for 10 million generations and sampled every 1,000th generation. The burn-in was determined as the point at which the average standard deviation of split frequencies was $<0.01$.

\section{Family Fellodistomidae Nicoll, 1909 \\ Genus Steringophorus Odhner, 1905}

\section{Steringophorus merretti n. sp.}

Syn. Steringophorus sp. ex Cataetyx laticeps of Bray et al. (1999)

Type-host: Cataetyx laticeps Koefoed (Ophidiiformes: Bythitidae).

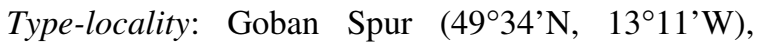
Northeastern Atlantic; depth 1,654 m; 07.vii.1994).

Type-specimens: Holotype (NHMUK 1998.8.17.5); paratypes (NHMUK 1998.8.17.6-8.).
Site in host: Intestine.

Representative DNA sequences: GenBank: AJ405259 (nad1) and AJ405299 (28S rDNA).

ZooBank registration: To comply with the regulations set out in article 8.5 of the amended 2012 version of the International Code of Zoological Nomenclature (ICZN, 2012), details of the new species have been submitted to ZooBank. The Life Science Identifier (LSID) for Steringophorus merretti n. sp. is urn:1sid:zoobank.org:act:1678B67B-9482-4D49-9028B48CCE3205E8.

Etymology: The species named for Dr Nigel Merrett in recognition of his major contributions to deep-sea biology and his expertise in abyssal trawling techniques.

\section{Description}

[Based on 6 whole-mounted, measured specimens and 2 sagittally sectioned specimens; Figs. 1, 2]. Body fusiform, rounded at each end; 1,260-1,664 $\times$ 420-525 (1,445 × 472); width 28.9-37.7 (32.8)\% of length (Fig. 1). Tegument unarmed, but particularly thick, especially posteriorly (Fig. 2a). Oral sucker (OS) rounded, subterminal, 155-172 × 148-182 (161 $\times 168$ ); length (L) 10.3-12.4 (11.2)\% of body-length (BL). Ventral sucker (VS) 218-271 × 209-278 (252 $\times$ 252); length 16.3-18.4 (17.5)\% of BL. Sucker ratios: length 1:1.40-1.68 (1.57); width (SWR) 1.36-1.69 (1.50). Forebody length (FBL) 352-471 (418), 25.5-32.7 (29.0)\% of BL. Prepharynx not detected. Pharynx $(\mathrm{Ph})$ oval, 69-100 × 83-91 $(85 \times$ 87); length 5.02-7.33 (5.92)\% of BL. OS to $\mathrm{Ph}$ width ratio 1: 0.49-0.61 (0.52). Oesophagus (Oes) 31-97 (62) long, 2.44-7.02 (4.26)\% of BL. Intestinal bifurcation (IB) in mid-body, 52-160 (129) from ventral sucker, 14.8-36.6 (30.3)\% of FBL. Caeca blind, fairly short, terminate in anterior post-testicular region 345-523 (453) from posterior extremity; post-caecal distance (PCD) 27.4-32.5 (30.9)\% of BL.

Cirrus-sac (CS) broad, oblong, thick-walled, 273-341 × 126-78 (312 × 153); length 20.5-23.4 (21.6)\% of BL. Internal seminal vesicle broad, tubular, convoluted, in posterior two-thirds of cirrus-sac. Prostatic cells accumulate around junction of seminal vesicle and ejaculatory duct. Ejaculatory duct broad, pocketed, may be protruded through genital pore as cirrus. Genital atrium wide, fairly shallow. Genital pore median or slightly sinistral, bifurcal. Testes (TT) 


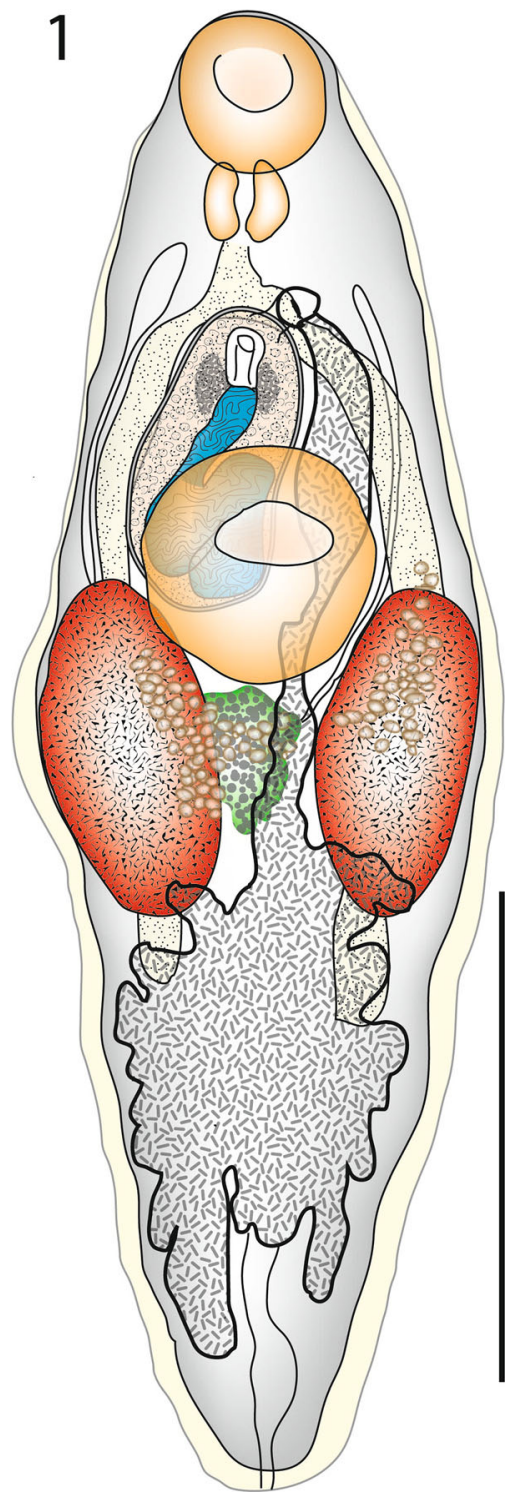

Fig. 1 Steringophorus merretti n. sp. Ventral view of holotype. Scale-bar: $500 \mu \mathrm{m}$

elongate-oval, smooth, symmetrical, in anterior hindbody and overlapping ventral sucker, close to lateral margins, $232-361 \times 109-202(303 \times 156)$; length 17.3-24.6 (21.1)\% of BL. Post-testicular region (PTR) 473-693 (575) long, 37.5-41.9 (39.7)\% of BL.

Ovary (Ov) follicular, overlaps ventral sucker and testes, not clearly delineated in whole-mounts, histologically rather amorphous (Fig. 2), 183-229 $\times$ 133-178 (202-156); length 12.6-15.5 (13.9)\% of BL. Seminal receptacle uterine. Laurer's canal opens dorsal to ovary (Fig. 2c). Uterus reaches to 119-205
(176) from posterior extremity; post-uterine distance (PUD) 8.30-15.8 (12.3)\% of BL. Metraterm of similar length to cirrus-sac, wide, thick-walled. Eggs tiny, 13-18 × 7-10 $(15 \times 9)$, possibly deformed but same in all specimens. Vitellarium in form of small lateral fields of small follicles, overlaps posterior margin of ventral sucker but does not reach posterior to testes; fields (VFL) 158-216 (183) long, 10.6-15.0 (12.7)\% of BL. Pre-vitelline distance (PrVD) 460-577 (533), 33.9-40.1 (37.0)\% of body-length; post-vitelline distance (PoVD) 592-919 (733), 46.3-55.2 (50.5)\% of BL.

Excretory pore terminal. Vesicle Y-shaped; branching point obscured by eggs; arms reach just prebifurcal.

\section{Differential diagnosis}

This is the only Steringophorus species reported from a bythitid and is notable for its tiny eggs, much smaller than reported for any other species of the genus. Steringophorus magnus Manter, 1934, with eggs 30-32 × 14-17 (Manter, 1934), and Steringophorus haedrichi Bray \& Campbell, 1995, with eggs 32-41 × 16-22 (Bray \& Campbell, 1995; Bray \& Gibson, 1998), are those species with the next smallest eggs. It may be that they are deformed, or poorly formed, in the material of the new species, as there is a lot of unattached shell material in the uterus, but all specimens have similar-sized eggs. Steringophorus merretti n. sp. has a relatively larger cirrus-sac (at length 20.5-23.4\% of BL) than any other species for which cirrus-sac measurements are available.

Steringophorus merretti $\mathrm{n}$. sp. also differs from the 14 other congeners thus:

Steringophorus arntzi Zdzitowiecki, 1997, from notothenioid fishes in the Weddell Sea, lacks an Oes, TT are smaller (c.14\% of BL), has a shorter PCD (c.15\% of BL), a shorter PTR (c.20-34\% of BL), a shorter PoVD (c.31-39\% of BL) and a shorter PUD (c.3\% of BL) (Zdzitowiecki, 1997; Zdzitowiecki, 2002a, 2002b).

Steringophorus blackeri Bray, 1973, from the alepocephalid Xenodermichthys copei (Gill) from the North Atlantic, is genetically distinct (see below), distinctly larger at 2,200-9,000 long, has a shorter FBL (c.16-22\% of BL), smaller VSL (c.5-9\% of BL), smaller SWR (c.1:0.96-1.16), smaller TT (at $2-7 \%$ of BL), longer PTR (c.55-70\% of BL), a smaller Ov (at 


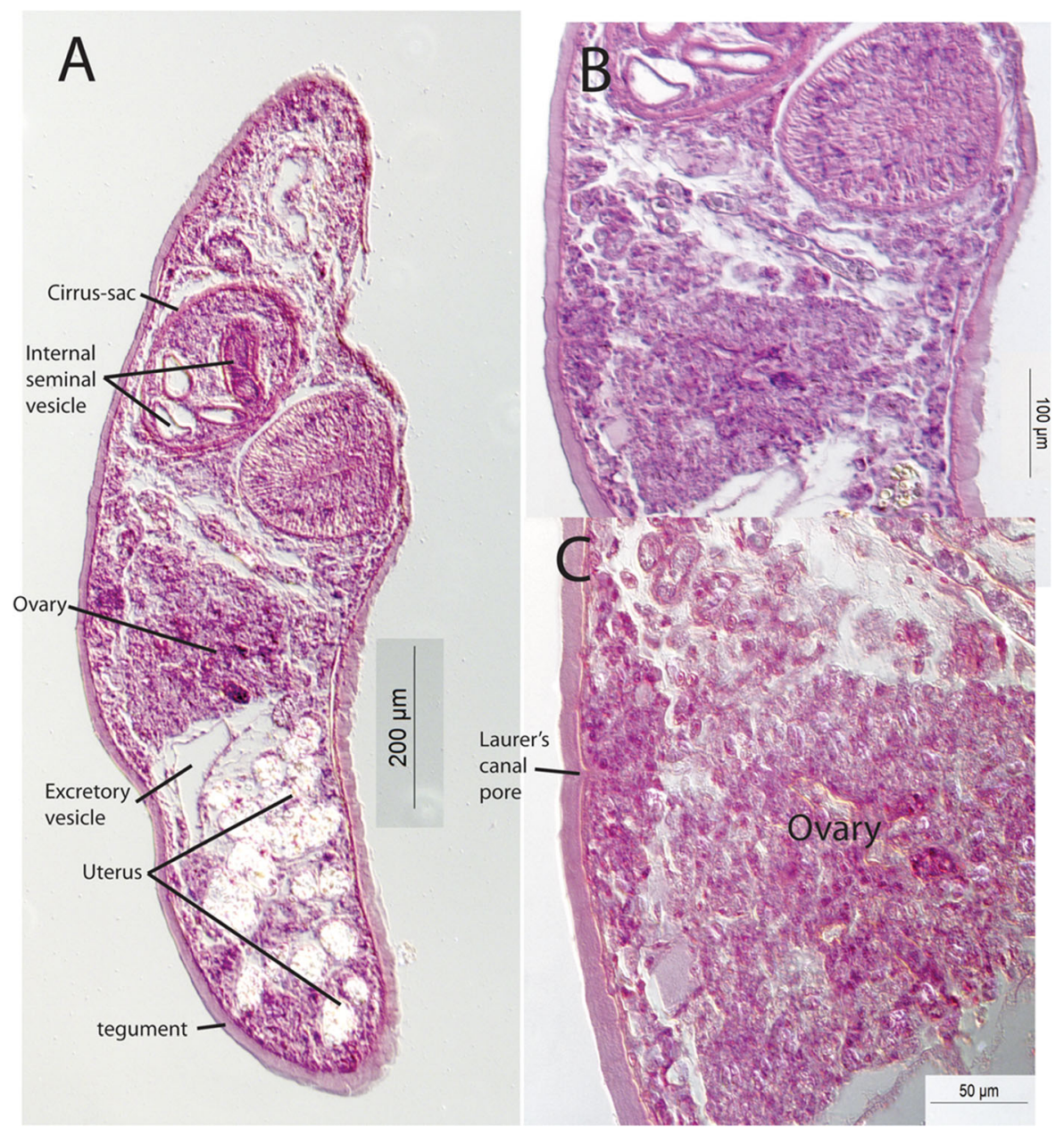

Fig. 2 Steringophorus merretti n. sp. Sagittal sections. A, Complete worm; B, Ventral sucker and anterior hindbody; C, Ovary and Laurer's canal opening

3-8\% of BL), shorter PrVD (c. 15-25\% of BL) and a longer vitellarium (c.19-27\% of BL) (Bray, 1973; Markle \& Wenner, 1979; Bray \& Gibson, 1980; Campbell, 1983; Aleshkina \& Gaevskaya, 1985; Bray \& Campbell, 1995; Bray et al., 1999).

Steringophorus congeri Shen, 1987 from congrid, bathylagid and microstomatid fishes in the northwestern Pacific Ocean, is distinctly larger at 4,040-10,268 long, a longer FBL (c.35\% of BL), smaller suckers (OSL c.8-9\%, VSL c. 10-11\% of BL), smaller $\mathrm{Ph}$ (length c.3-4\% of BL), longer Oes (c.8-10\% of BL), a shorter PCD (c.15\% of BL), smaller TT (length 7-8\% of BL), smaller Ov (c.7-8 of $\mathrm{BL})$, a longer vitellarium (c.30\% of BL) and a shorter PoVD (c.40\% of BL) (Shen, 1987; Kuramochi, 2009).
Steringophorus dorsolineatus (Reimer, 1985) Bray, 1995 (syn. Occultacetabulum dorsolineatum Reimer, 1985) from ipnopidae fishes of the genus Bathypterois in the south-western Indian Ocean, the Atlantic and probably the Mediterranean Sea, is genetically distinct (see below), has a smaller VSL (length $c .8-14 \%$ of BL), smaller SWR (1:0.84-1.06), the Oes is generally longer (5-10\% of BL), a shorter PCD (c.13-14\% of $\mathrm{BL}$ ), smaller TT (length 7-9\% of BL), smaller Ov (c.6-8 of BL), a longer vitellarium (c.21-26\% of BL) and a shorter PoVD (c.34-36\% of BL) (Reimer, 1985; Bray, 1995; Bray \& Kuchta, 2006; Mateu et al., 2014).

Steringophorus foliatus (Yamaguti, 1970) Bray \& Gibson, 1980 (syn. Callodistomoides foliatus Yamaguti, 1970) from an unidentified inermiid fish of the genus Emmelichthyops off Hawaii, has a smaller OSL 
(c.7\% of BL), smaller PhL (c.3.5\% of BL), a shorter PCD (c. $10 \%$ of BL) and smaller TT (length $8-11 \%$ of BL) (Yamaguti, 1970). Randall (2007) does not include any Emmelichthyops species in his book on Hawaiian marine fishes. On the other hand, he does include three species of Emmelichthys. These species are found at bathyal depths, with the golden rover $E$. scintillans (Jordan \& Thompson) reported to $606 \mathrm{~m}$, so it could possibly harbour Steringophorus.

Steringophorus furciger (Olsson, 1868) Odhner, 1905 (syns Distoma furcigerum Olsson, 1868; Leioderma furcigerum (Olsson, 1868) Stafford, 1904; Fellodistomum furcigerum (Olsson, 1868) Yamaguti, 1954) from many fish species, particularly pleuronectids, from the northern parts of the Atlantic and Pacific Oceans, is genetically distinct (Fig. 3). It is a commonly recorded species and has been described many times (Olsson, 1868; Levinsen, 1881; Odhner, 1905; Lebour, 1908; Yamaguti, 1934; Linton, 1940; Miller, 1941; Polyanski, 1955; Strelkov, 1960; Bray \& Gibson, 1980; Machida, 1988; Bray \& Campbell, 1995). It is debatable if all the records attributed to this species are accurate, but apart from the egg and cirrussac size difference, the testes tend to be smaller (c.7-15\% of BL) and the vitelline length is larger (c.19-26\% of BL). Bray \& Gibson (1980) and Machida (1988) discussed the variation found in this species, and particularly that of the egg-size, but all published measurements are distinctly larger to much larger than in $S$. merretti $\mathrm{n}$. sp.

Steringophorus haedrichi Bray \& Campbell, 1995 from ophidiid fishes in the north-eastern Atlantic, is genetically distinct (see below), is distinctly larger at 3,514-5,692, with a smaller VSL (c.11-14\% of BL), a shorter PCD (c.23-24\% of BL), smaller TT (length $10-13 \%$ of BL) and a smaller Ov (c.8-10 of BL) (Bray \& Campbell, 1995; Bray \& Gibson, 1998; Bray et al., 1999).

Steringophorus liparidis Zdzitowiecki, 1997 from liparid and muraenolepidid fishes from the Weddell and Ross Seas, grows distinctly larger at 2,000-6,418 long, has a smaller VSL (c.13-14\% of BL), a shorter PCD (c.7-11\% of BL), shorter PTR (c.21-35\% of BL) and a longer vitellarium (c.23-24\% of BL) (Zdzitowiecki, 1997; Sokolov \& Gordeev, 2015).

Steringophorus magnus Manter, 1934 from "unidentified eel-like fish" off Florida, is distinctly larger at 6,080-7,220 long, with a shorter FBL (c.20\% of BL), smaller OSL (c.6-7\% of BL), smaller VSL (c.13-15\% of BL), larger SWR (1:2.18-2.45), longer PCD (c.38\% of BL) and longer PTR (c.51\% of BL) (Manter, 1934).

Steringophorus margolisi Bray, 1995 from the ophidiid fish Spectrunculus grandis (Günther), in the north-eastern Atlantic, is genetically distinct (see below), is distinctly larger at 4,659-5,840 long, narrower (width 22-23\% of BL), shorter FBL (9-23 of BL), smaller OSL (c.7-9\% of BL), smaller VSL (c.8-9\% of BL), smaller SWR (1:1.23-1.33), shorter PCD ( $8 \%$ of BL), smaller TT (length $7 \%$ of BL), longer PTR (c.56-61\% of BL), smaller OvL (c.5\% of $\mathrm{BL})$, smaller PrVD (c.27\% of BL) and longer VFL (c.27\% of BL) (Bray, 1995; Bray et al., 1999; Olson et al., 2003; Bray \& Kuchta, 2006).

Steringophorus melanostigmum (Noble \& Orias, 1975) (syns. Fellodistomum melanostigmum Noble \& Orias, 1975; Benthotrema melanostigmi Parukhin \& Lyadov, 1979) from zoarcid fishes of the genus Melanostigma in the Pacific, Indian and Atlantic Ocean, grows distinctly larger at 1,435-4,920 long, with a smaller VSL (c.7-9\% BL), smaller SWR (1:0.97-1.12), shorter Oes (c.0-2\% of BL), testes usually smaller (c.4-18\% of BL), longer PTR (c.48-50\% of BL), usually smaller OvL (c.4-16\% of $\mathrm{BL}$ ), shorter PrVD (c.15-28\% of BL) and a longer VFL (c.24-31\% of BL). Benthotrema melanostigmi is presently considered a synonym of $S$. melanostigmum, but certain characters such as the size of the gonads and the anterior extent of the vitellarium suggest that it may be distinct (Noble \& Orias, 1975; Markle \& Wenner, 1979; Parukhin \& Lyadov, 1979).

Steringophorus pritchardae (Campbell, 1975) Bray \& Gibson, 1980 (syn. Abyssotrema pritchardae Campbell, 1975) mainly from alepocephalid fishes of the genus Alepocephalus, with one report from a morid, from the north Atlantic Ocean, is genetically distinct (see below), is distinctly larger at $3,900-13,800$ long, with a shorter FBL (c.20-22\% of BL), smaller OSL (c.5-10\% of BL), smaller VSL (c.4-8\% of BL), smaller SWR (c.1:0.81-1.06), smaller PCD (c.22\% of BL), smaller TTL (c.4-9\% of BL), smaller OvL (c.4-6\% of BL), smaller PrVD (25-28\% of BL) and a longer VFL (c. 26-35\% of BL) (Campbell, 1975; Bray \& Gibson, 1980; Campbell et al., 1980; Gaevskaya \& Aleshkina, 1983; Bray et al., 1999; Bray \& Kuchta, 2006; Gordeev et al., 2019).

Steringophorus profundus Manter, 1934 from the argentinid fish Argentina striata Goode \& Bean off 


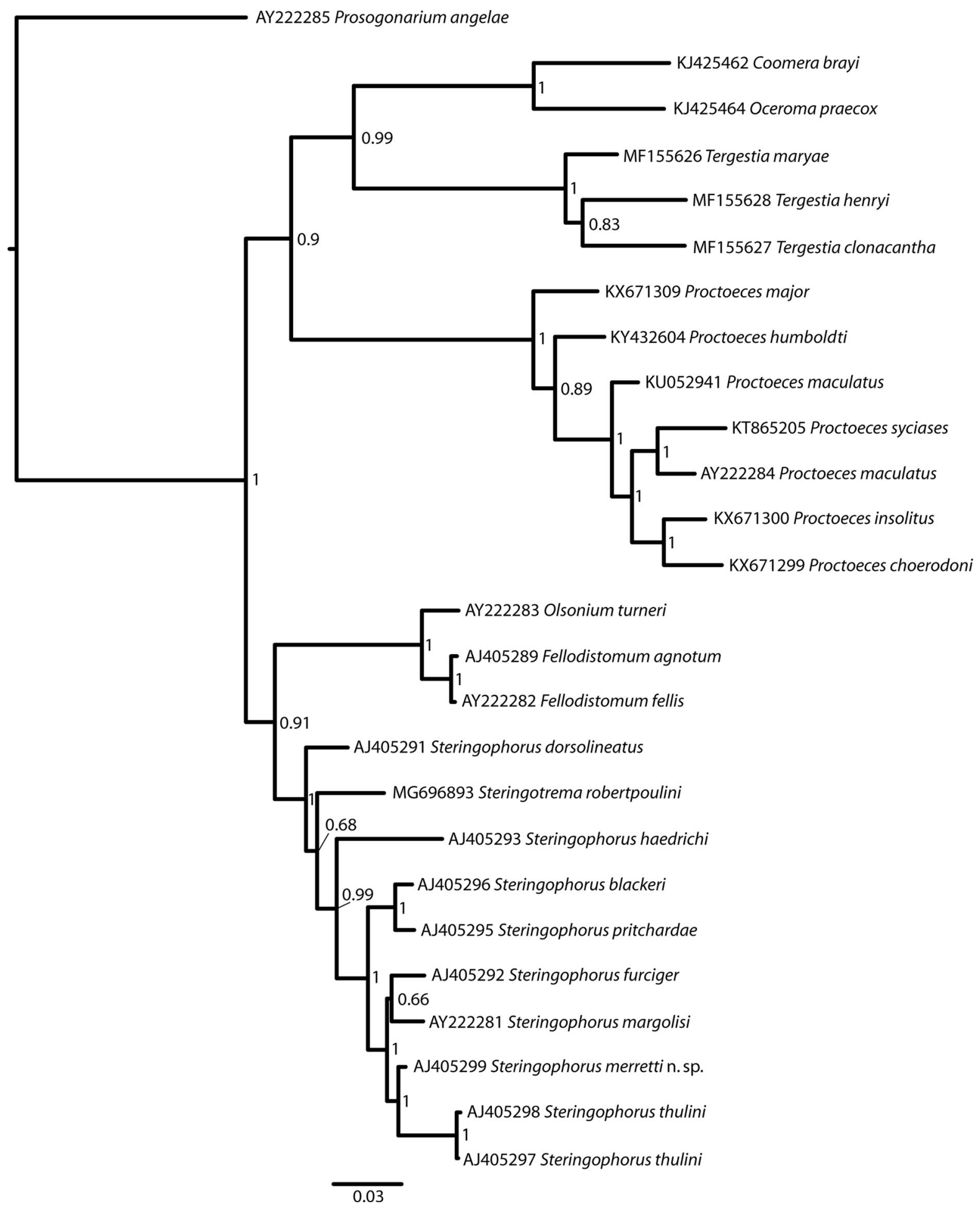

Fig. 3 Bayesian analysis of available fellodistomid 28S rDNA sequences. Tree constructed using MrBayes version 3.2.1 under the GTR $+\mathrm{I}+\mathrm{G}$ model of nucleotide evolution; 10,000,000 generations, 5,000,000 generations 'burn-in' 
Florida, is slightly wider (c.40-45\% of BL), with a shorter PCD (c.40\% of BL), longer VFL (c.23\% of BL) and shorter PoVD (c.42\% of BL) (Manter, 1934).

Steringophorus thulini Bray \& Gibson, 1980 (syn. Callodistomoides foliatus of Zubchenko, 1975) from macrourids (mainly) and lotids in the northern Atlantic Ocean, is genetically distinct (see below), has longer caeca (PCD 16-19\% of BL), smaller TT (12-16\% of $\mathrm{BL})$, shorter PTR (26-36\% of BL), longer VFL (22-25\% of BL) and shorter PoVD (36-45\% of BL) (Zubchenko, 1975; Bray \& Gibson, 1980; Bray, 1995; Bray et al., 1999; Kellermanns et al., 2009).

\section{Molecular phylogeny}

Molecular results indicate that Steringophorus merretti is distinct from all other Steringophorus species for which sequences are available. A molecular phylogeny, inferred from $28 \mathrm{~S}$ rDNA sequences obtained from GenBank (Table 1), is presented in Fig. 3. This is similar to that published by Pérez-Ponce de León et al. (2018) but includes more shallow waters species of the genera Tergestia Stossich, 1899 and Proctoeces Odhner, 1911 in addition to $S$. merretti. In Table 1, we have included bathymetric data for these species, when available, which, in conjunction with the tree, shows that the family Fellodistomidae consists of two readily distinguished clades, characterised by the bathymetry of the species. The main caveat with this finding is the position of the shallowwater form Steringotrema robertpoulini Pérez-Ponce de León, Anglade \& Randhawa, 2018. This species is from the New Zealand sole Peltorhamphus novaezeelandiae Günther (Pleuronectidae) off South Island, New Zealand (Pérez-Ponce de León et al., 2018). According to Froese \& Pauly (2019) it 'inhabits shallow waters, generally at depth of less than 50 m'. It is the only member of its genus for which molecular data are available, so it is not currently possible to state that this a genuinely anomalous position or that a group of related species have invaded shallow water.

Pleuronectiforms are not rare hosts of Steringophorus spp. (see below), but the vast majority of reports are of the species S. furciger, a species which is thought to range into deeper waters (Bray, 2004). Steringophorus merretti is resolved as the sister species of another deep-sea species, S. thulini, and is embedded within a clade of deep-sea species.

\section{Steringophorus Odhner, 1905}

We are aware of 338 host/parasite reports of the 15 members of this genus, 242 (72\%) of which are of $S$. furciger. Therefore, in any discussion of the biological characteristics of the genus, the predominance of data on this species must be considered. If we look at the fish orders harbouring species of Steringophorus (Fig. 4), we see a predominance of reports in the pleuronectiforms (55\%). Considering S. furciger (Fig. 5) only, we see that $76 \%$ of records are from this order, but non-furciger species have about $4 \%$ of records from this order, and none are identified to species and may well be $S$. furciger (see Arthur \& Albert, 1994; Chambers, 2008). The predominant host orders for non-furciger species are the deep-water taxa, the Osmeriformes (with $28 \%$ of records) and the Gadiformes (22\%) (Fig. 6). Other predominantly deep-sea orders constitute the majority of the other reports: Ophidiiformes (11\%), Aulopiformes (8\%), Scorpaeniformes (3\%) and Argentiformes (3\%). Even the perciform hosts reported for Steringophorus spp. (10\% for S. furciger, $15 \%$ for non-furciger species) are almost entirely zoarcids (with many upper bathyal species) or Antarctic notothenioids (Artedidraconidae, Bathydraconidae). The genus is, therefore, predominantly found in deep-sea or demersal cold-water fishes.

The distribution patterns are mapped in Fig. 7, showing the ecoregions of Spalding et al. (2007), with the red circles referring to Steringophorus spp. and the orange circles to Steringotrema spp. The numbers in the red circles (which are not to strictly to scale but give some impression of the number of records) are the number of records of all Steringophorus species, followed by the number of $S$. furciger records separated by a comma. All reports of $S$. furciger, and the vast majority of all records, are in the high northern latitudes. The infrequent reports from elsewhere may be affected by sampling effort but are also likely to be indicative of a genuine dearth, as findings of Steringophorus spp. are virtually absent from among the many reports of digeneans from tropical and subtropical regions. Existing reports from apparently warm water regions should be examined closely. For example, the report of specimens from ecoregion 20 (Western Indian Ocean) is of $S$. dorsolineatus from the deep-sea ipnopid Bathypterois phenax Parr (Reimer, 1985). The three records in ecoregion 17 (Gulf of 
Table 1 Data on the 28S rDNA sequences used in the phylogenetic analysis

\begin{tabular}{|c|c|c|c|c|c|}
\hline GenBank ID & Parasite & Host & Locality & Depth & Reference \\
\hline AY222285 & $\begin{array}{l}\text { Prosogonarium angelae Cribb \& Bray, } \\
1994\end{array}$ & Euristhus lepturus & $\begin{array}{l}\text { Moreton Bay, } \\
\text { Queensland, } \\
\text { Australia }\end{array}$ & Shallow & $\begin{array}{l}\text { Olson et al. } \\
\text { (2003) }\end{array}$ \\
\hline KJ425462 & Coomera brayi Dove \& Cribb, 1995 & $\begin{array}{l}\text { Monodactylus } \\
\text { argenteus }\end{array}$ & $\begin{array}{l}\text { Moreton Bay, } \\
\text { Queensland, } \\
\text { Australia }\end{array}$ & Shallow & $\begin{array}{l}\text { Cribb et al. } \\
(2014)\end{array}$ \\
\hline KJ425464 & Ocerama praecox (Walker, 1971) & Scorpis lineolata & $\begin{array}{l}\text { Moreton Bay, } \\
\text { Queensland, } \\
\text { Australia }\end{array}$ & Shallow & $\begin{array}{l}\text { Cribb et al. } \\
(2014)\end{array}$ \\
\hline MF155626 & $\begin{array}{l}\text { Tergestia maryae Wee, Cutmore, Yong \& } \\
\text { Cribb, } 2017\end{array}$ & Alepes apercna & $\begin{array}{l}\text { Moreton Bay, } \\
\text { Queensland, } \\
\text { Australia }\end{array}$ & Shallow & $\begin{array}{l}\text { Wee et al. } \\
\text { (2017b) }\end{array}$ \\
\hline MF155628 & $\begin{array}{l}\text { Tergestia henryi Wee, Cutmore, Yong \& } \\
\text { Cribb, } 2017\end{array}$ & $\begin{array}{l}\text { Pantolabus } \\
\text { radiatus }\end{array}$ & $\begin{array}{l}\text { Moreton Bay, } \\
\text { Queensland, } \\
\text { Australia }\end{array}$ & Shallow & $\begin{array}{l}\text { Wee et al. } \\
\text { (2017b) }\end{array}$ \\
\hline MF155627 & Tergestia clonacantha Manter, 1963 & $\begin{array}{l}\text { Hyporhamphus } \\
\text { regularis } \\
\text { ardelio }\end{array}$ & $\begin{array}{l}\text { Moreton Bay, } \\
\text { Queensland, } \\
\text { Australia }\end{array}$ & Shallow & $\begin{array}{l}\text { Wee et al. } \\
\text { (2017b) }\end{array}$ \\
\hline KX671309 & Proctoeces major Yamaguti, 1934 & $\begin{array}{l}\text { Monodactylus } \\
\text { argenteus }\end{array}$ & $\begin{array}{l}\text { Moreton Bay, } \\
\text { Queensland }\end{array}$ & Shallow & $\begin{array}{l}\text { Wee et al. } \\
\text { (2017a) }\end{array}$ \\
\hline KY432604 & $\begin{array}{l}\text { Proctoeces humboldti George- } \\
\text { Nascimento \& Quiroga, } 1983\end{array}$ & $\begin{array}{l}\text { Sicyases } \\
\quad \text { sanguineus }\end{array}$ & Coquimbo, Chile & Shallow & $\begin{array}{l}\text { Oliva et al. } \\
\text { (2018) }\end{array}$ \\
\hline KU052941 & Proctoeces maculatus (Looss, 1901) & Sabella pavonina & $\begin{array}{l}\text { Bizerte Lagoon, } \\
\text { Tunisia }\end{array}$ & Shallow & $\begin{array}{l}\text { Antar \& } \\
\text { Gargouri } \\
(2016)\end{array}$ \\
\hline KT865205 & $\begin{array}{l}\text { Proctoeces syciases Oliva, Valdivia, } \\
\text { Cárdena, Muñoz, Escribano \& George- } \\
\text { Nascimento, } 2018\end{array}$ & $\begin{array}{l}\text { Sicyases } \\
\quad \text { sanguineus }\end{array}$ & Iquique, Chile & Shallow & $\begin{array}{l}\text { Oliva et al. } \\
\text { (2018) }\end{array}$ \\
\hline AY222284 & Proctoeces maculatus & $\begin{array}{l}\text { Archosargus } \\
\quad \text { probatocephalus }\end{array}$ & $\begin{array}{l}\text { Gulf of Mexico, } \\
\text { Mississippi, } \\
\text { USA }\end{array}$ & Shallow & $\begin{array}{l}\text { Olson et al. } \\
(2003)\end{array}$ \\
\hline KX671300 & Proctoeces insolitus (Nicoll, 1915) & $\begin{array}{l}\text { Acanthopagrus } \\
\text { australis }\end{array}$ & $\begin{array}{l}\text { Moreton Bay, } \\
\text { Queensland, } \\
\text { Australia }\end{array}$ & Shallow & $\begin{array}{l}\text { Wee et al. } \\
\text { (2017a) }\end{array}$ \\
\hline KX671299 & $\begin{array}{l}\text { Proctoeces choerodoni Wee, Cribb, Bray } \\
\quad \text { \& Cutmore, } 2017\end{array}$ & $\begin{array}{r}\text { Choerodon } \\
\text { cyanodus }\end{array}$ & $\begin{array}{l}\text { Off Heron Island, } \\
\text { Queensland, } \\
\text { Australia }\end{array}$ & Shallow & $\begin{array}{l}\text { Wee et al. } \\
\text { (2017a) }\end{array}$ \\
\hline AY222283 & Olsonium turneri Bray \& Gibson, 1980 & $\begin{array}{l}\text { Alepocephalus } \\
\text { agassizii }\end{array}$ & $\begin{array}{l}\text { Porcupine } \\
\text { Seabight, NE } \\
\text { Atlantic }\end{array}$ & $2,441 \mathrm{~m}$ & $\begin{array}{l}\text { Olson et al. } \\
\text { (2003) }\end{array}$ \\
\hline AJ405289 & Fellodistomum agnotum Nicoll, 1909 & Anarhichas lupus & North Sea & $135 \mathrm{~m}$ & $\begin{array}{l}\text { Bray et al. } \\
\text { (1999) }\end{array}$ \\
\hline AY222282 & Fellodistomum fellis (Olsson, 1868) & Anarhichas lupus & North Sea & $135 \mathrm{~m}$ & $\begin{array}{l}\text { Olson et al. } \\
\text { (2003) }\end{array}$ \\
\hline AJ405291 & $\begin{array}{l}\text { Steringophorus dorsolineatus (Reimer, } \\
\text { 1985) }\end{array}$ & $\begin{array}{l}\text { Bathypterois } \\
\text { dubius }\end{array}$ & $\begin{array}{l}\text { Goban Spur, NE } \\
\text { Atlantic }\end{array}$ & $1,541 \mathrm{~m}$ & $\begin{array}{l}\text { Bray et al. } \\
\text { (1999) }\end{array}$ \\
\hline MG696893 & $\begin{array}{l}\text { Steringotrema robertpoulini Pérez-Ponce } \\
\text { de León, Anglade \& Randhawa, } 2018\end{array}$ & $\begin{array}{l}\text { Peltorhamphus } \\
\text { novaezeelandiae }\end{array}$ & $\begin{array}{l}\text { South Island, } \\
\text { New Zealand }\end{array}$ & Shallow & $\begin{array}{l}\text { Pérez-Ponce } \\
\text { de León } \\
\text { et al. (2018) }\end{array}$ \\
\hline AJ405293 & $\begin{array}{l}\text { Steringophorus haedrichi Bray \& } \\
\text { Campbell, } 1995\end{array}$ & $\begin{array}{l}\text { Spectrunculus } \\
\text { grandis }\end{array}$ & $\begin{array}{l}\text { Goban Spur, NE } \\
\text { Atlantic }\end{array}$ & $2,570 \mathrm{~m}$ & $\begin{array}{l}\text { Bray et al. } \\
\text { (1999) }\end{array}$ \\
\hline
\end{tabular}


Table 1 continued

\begin{tabular}{|c|c|c|c|c|c|}
\hline GenBank ID & Parasite & Host & Locality & Depth & Reference \\
\hline AJ405296 & Steringophorus blackeri Bray, 1973 & $\begin{array}{l}\text { Xenodermichthys } \\
\text { copei }\end{array}$ & $\begin{array}{l}\text { Goban Spur, NE } \\
\text { Atlantic }\end{array}$ & $960 \mathrm{~m}$ & $\begin{array}{l}\text { Bray et al. } \\
\quad(1999)\end{array}$ \\
\hline AJ405295 & $\begin{array}{l}\text { Steringophorus pritchardae (Campbell, } \\
\text { 1975) }\end{array}$ & $\begin{array}{l}\text { Alepocephalus } \\
\text { rostratus }\end{array}$ & $\begin{array}{l}\text { Goban Spur, NE } \\
\text { Atlantic }\end{array}$ & $1,625 \mathrm{~m}$ & $\begin{array}{l}\text { Bray et al. } \\
\text { (1999) }\end{array}$ \\
\hline AJ405292 & Steringophorus furciger (Olsson, 1868) & Limanda limanda & $\begin{array}{c}\text { Off St Abbs, } \\
\text { North Sea }\end{array}$ & $59 \mathrm{~m}$ & $\begin{array}{l}\text { Bray et al. } \\
\text { (1999) }\end{array}$ \\
\hline AY222281 & Steringophorus margolisi Bray, 1995 & $\begin{array}{l}\text { Spectrunculus } \\
\text { grandis }\end{array}$ & $\begin{array}{l}\text { Rockall Trough, } \\
\text { NE Atlantic }\end{array}$ & $\begin{array}{l}1,745-1,760 \\
\mathrm{~m}\end{array}$ & $\begin{array}{l}\text { Olson et al } \\
\quad(2003)\end{array}$ \\
\hline AJ405299 & Steringophorus merretti n. sp. & Cataetyx laticeps & $\begin{array}{l}\text { Goban Spur, NE } \\
\text { Atlantic }\end{array}$ & $1,654 \mathrm{~m}$ & $\begin{array}{l}\text { Bray et al. } \\
\text { (1999) }\end{array}$ \\
\hline AJ405298 & $\begin{array}{l}\text { Steringophorus thulini Bray \& Gibson, } \\
\quad 1980\end{array}$ & $\begin{array}{l}\text { Coryphaenoides } \\
\text { leptolepis }\end{array}$ & $\begin{array}{l}\text { Porcupine } \\
\text { Abyssal Plain }\end{array}$ & $4,100 \mathrm{~m}$ & $\begin{array}{l}\text { Bray et al. } \\
\quad(1999)\end{array}$ \\
\hline AJ405297 & Steringophorus thulini & $\begin{array}{l}\text { Coryphaenoides } \\
\text { mediterranea }\end{array}$ & $\begin{array}{l}\text { Rockall Trough, } \\
\text { NE Atlantic }\end{array}$ & $\begin{array}{l}1,745-1,760 \\
\mathrm{~m}\end{array}$ & $\begin{array}{l}\text { Bray et al. } \\
\text { (1999) }\end{array}$ \\
\hline
\end{tabular}

Guinea) are of parasites of members of the deep-sea family Alepocephalidae (Gaevskaya \& Aleshkina, 1983; Aleshkina \& Gaevskaya, 1985). The report from off northern Chile (ecoregion 45, Warm Temperate Southeastern Pacific) is of an unnamed species from the macrourid Coryphaenoides ariommus Gilbert \& Thompson (Nacari \& Oliva, 2016). All reports with identified hosts from the Gulf of Mexico (ecoregion 6, Warm Temperate Northwest Atlantic, and ecoregion

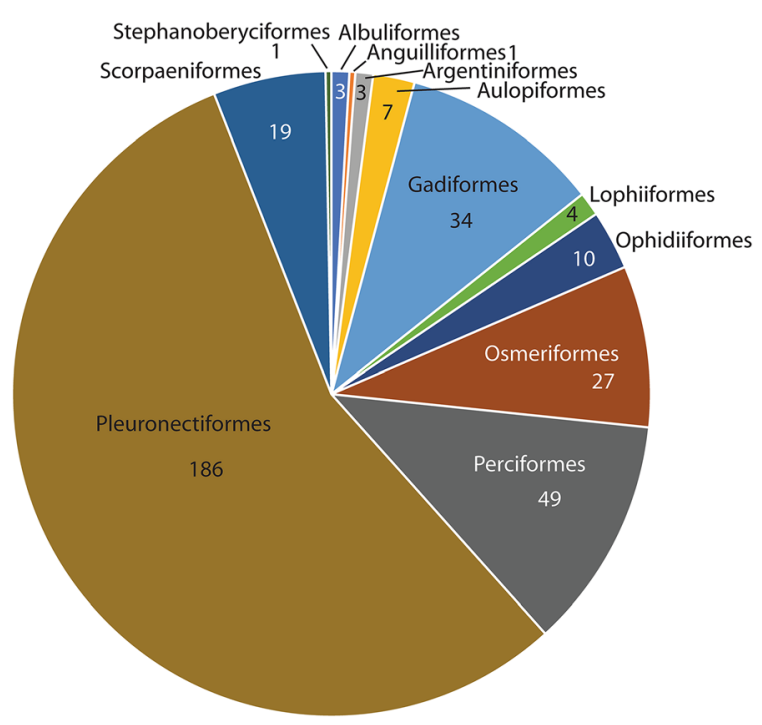

Fig. 4 Pie graph showing records from host orders: All Steringophorus records
12, Tropical Northwestern Atlantic) are from the deepsea families Ophidiidae, Argentinidae or Alepocephalidae (Manter, 1934, 1947; Harris \& Dronen, 1999). There is no evidence that species of Steringophorus occur in shallow-water or reef fishes in lower latitudes.

\section{Steringotrema Odhner, 1911}

As Steringotrema robertpoulini is, apparently, embedded within Steringophorus, according to our tree (Fig. 3) and that of Pérez-Ponce de León et al. (2018), it seems appropriate to discuss this genus and its relationship with Steringophorus. According to Bray (2002), the genera are distinguished by the vitelline configuration of their constituent species, the shape of the ovary and the excretory vesicle. In Steringotrema spp. the vitellarium is mainly, or has a significant proportion, in the forebody, whereas in Steringophorus the vitellarium is mainly in the hindbody. The ovary is multilobate in Steringophorus spp., but in Steringotrema spp. the ovary is entire or tri-lobed. The excretory vesicle is Y-shaped in Steringophorus spp. and V-shaped in Steringotrema spp. Individual species in these genera exhibit some variation in these features. For example, in Steringophorus dorsolineatum, the ovary was originally described as smooth ("glattrandig") (Reimer, 1985) and later as "weakly multilobate" (Bray, 1995). It remains to be seen how useful these characters are in reflecting the 


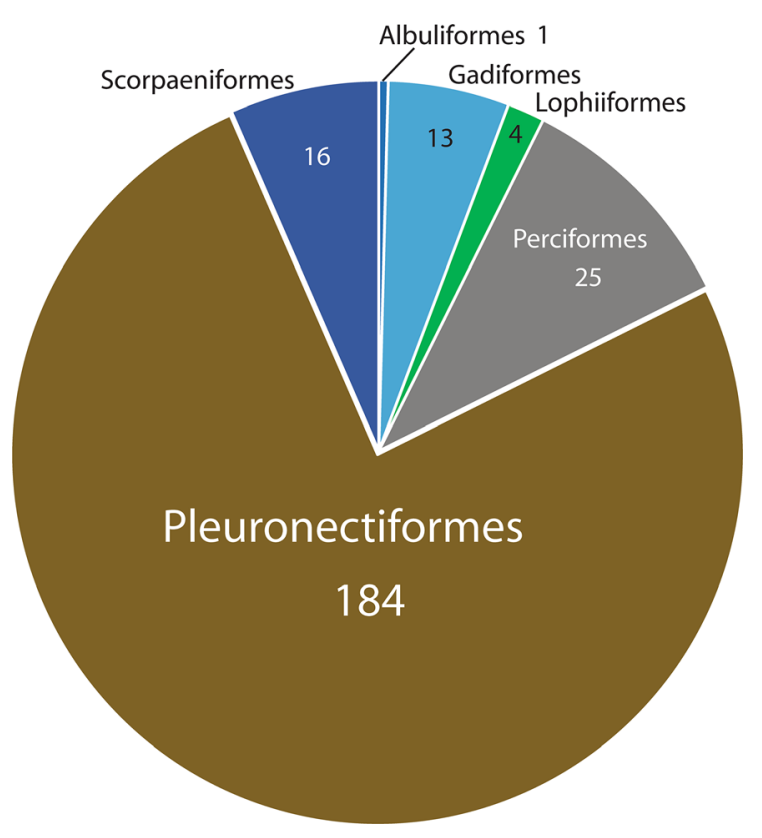

Fig. 5 Pie graph showing records from host orders: All $S$. furciger records

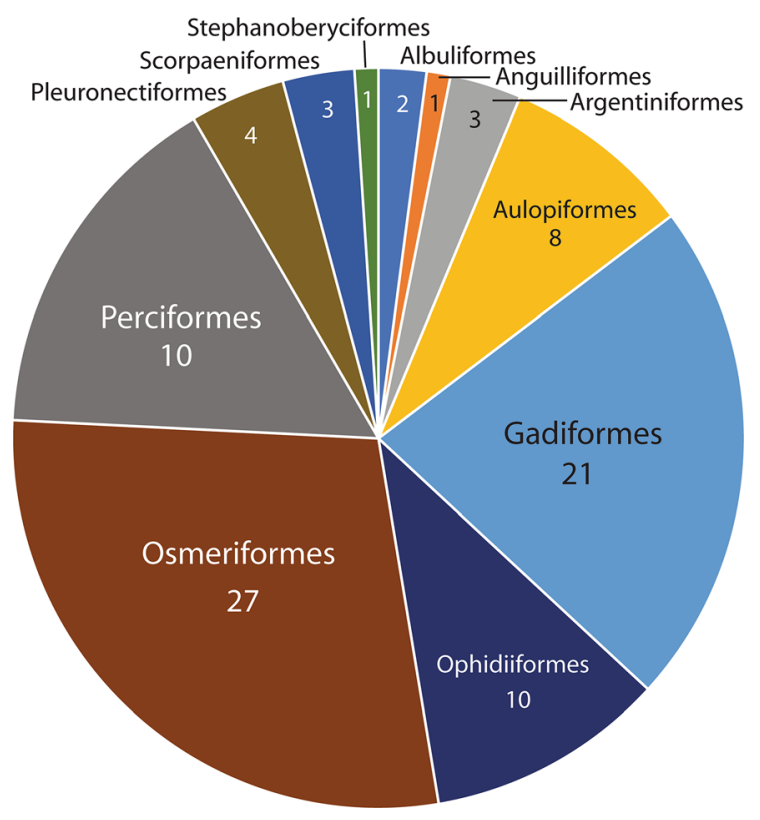

Fig. 6 Pie graph showing records from host orders: All nonfurciger records

phylogenetic relationships within this family. The relationships of these genera and the closely similar genera Lomasoma Manter, 1935, Megenteron Manter,
1934, Prudhoeus Bray \& Gibson, 1980 and Steringovermis Bray, 2004 await molecular study.

We are aware of 176 host/parasite records of 12 Steringotrema spp. There is no single predominant species, but three species make up $81 \%$ of records. These are the northern temperate species $S$. pagelli (van Beneden, 1871) (35\%), S. ovacutum (Lebour, 1908) (28\%) and S. divergens (Rudolphi, 1809) (18\%). Perciformes (53\%) and Pleuronectiformes (43\%) are the predominant host groups (Fig. 8). There are six records from Gadiformes, four of which are not identified to species, and there are single records of named species from Clupeiformes and Tetraodontiformes. In contrast to Steringophorus, the majority of reports from perciform hosts are from the shallow water groups Sparidae (50\%) and Blennidae (23\%). Kellermanns et al. (2009) found an unnamed Steringotrema in the macrourid Coryphaenoides mediterraneus (Giglioli) from the Charlie-Gibbs Fracture Zone on the Mid-Atlantic Ridge, with a range of depths for the host species (but not necessarily for the parasite) of 1,700-3,050 m. Nevertheless, the finding in a macrourid is certainly worthy of note as an anomalous finding for the parasite. Other records of Steringotrema spp. in macrourids are by Palm \& Klimpel (2008) ('Steringotrema pagelli' in Macrourus berglax Lacépède, depth 278-423 m, Irminger Sea) and Constenla et al. (2015) (Steringotrema sp., in Trachyrincus scabrus (Rafinesque), depth 574-1,000 m, Western Mediterranean). Further deep-water records are by Kuramochi (2014) (Steringotrema sp. in Bothrocara hollandi (Jordan \& Hubbs), Zoarcidae, depth 1,394-1,400 m, Sea of Japan) and Dallarés et al. (2016) (Steringotrema sp. in Phycis blennoides (Brünnich), Phycidae, 400-1,000 m, Balearic Sea). In no cases were descriptions given. Nevertheless, most evidence points to Steringotrema species being denizens of shallow-waters, whereas Steringophorus species are adapted to deeper-waters.

Steringotrema spp. are distributed mainly in cold to temperate waters, with most records in the northern parts of the Atlantic and Pacific Oceans (Fig. 7). They may be more tolerant of warmer waters than Steringophorus spp.; for example, it is much more commonly reported in the Mediterranean Sea (i.e. ecoregion 4). The few reports from warm waters are, however, not definitive. Fischthal \& Thomas (1968) reported, but did not describe, three immature specimens of Markevitschiella sp. (a genus widely 


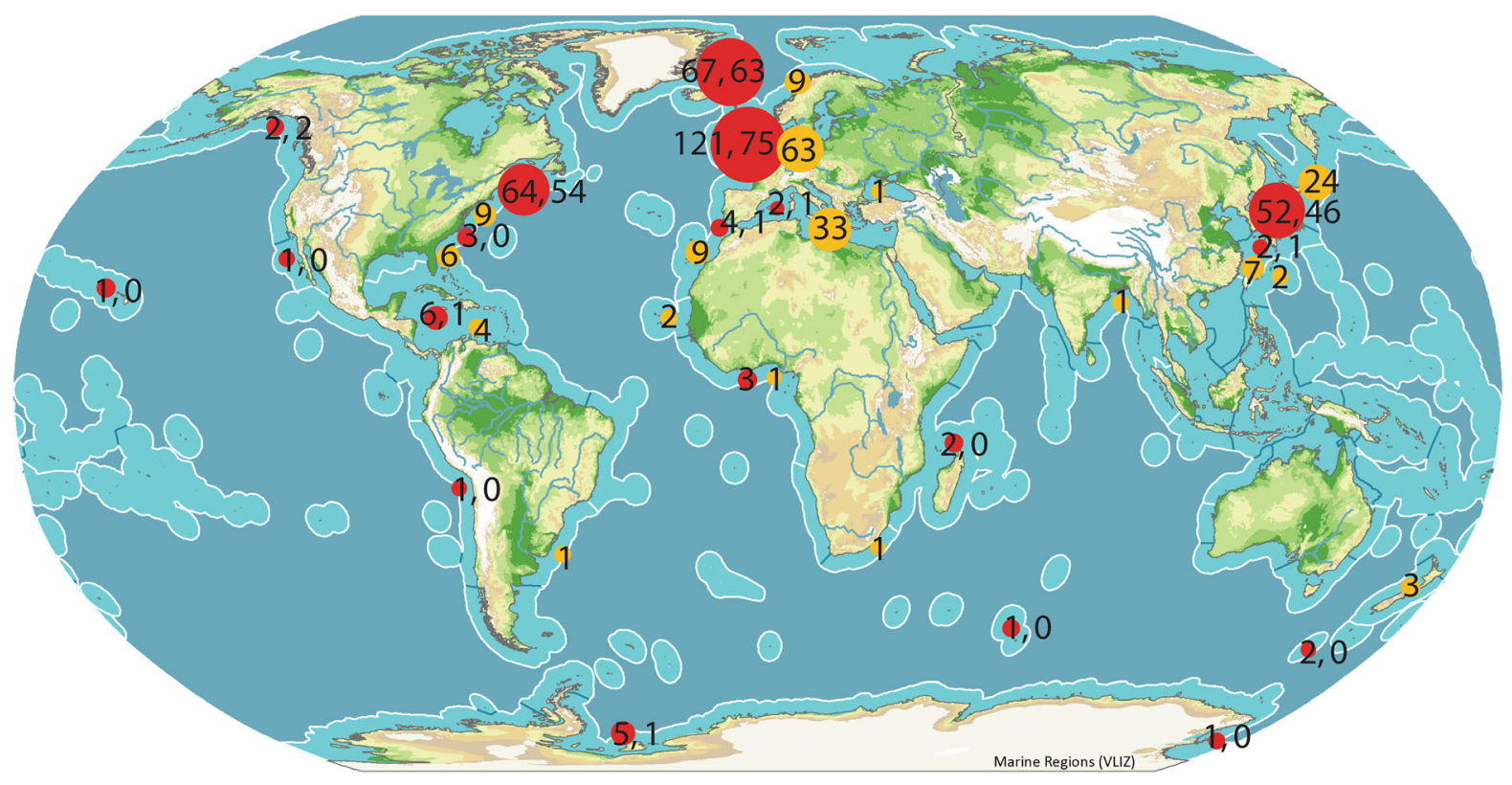

Fig. 7 Global distribution of Steringophorus and Steringotrema records plotted on Spalding et al. (2007) ecoregions. Red circles, Steringophorus; orange circles Steringotrema

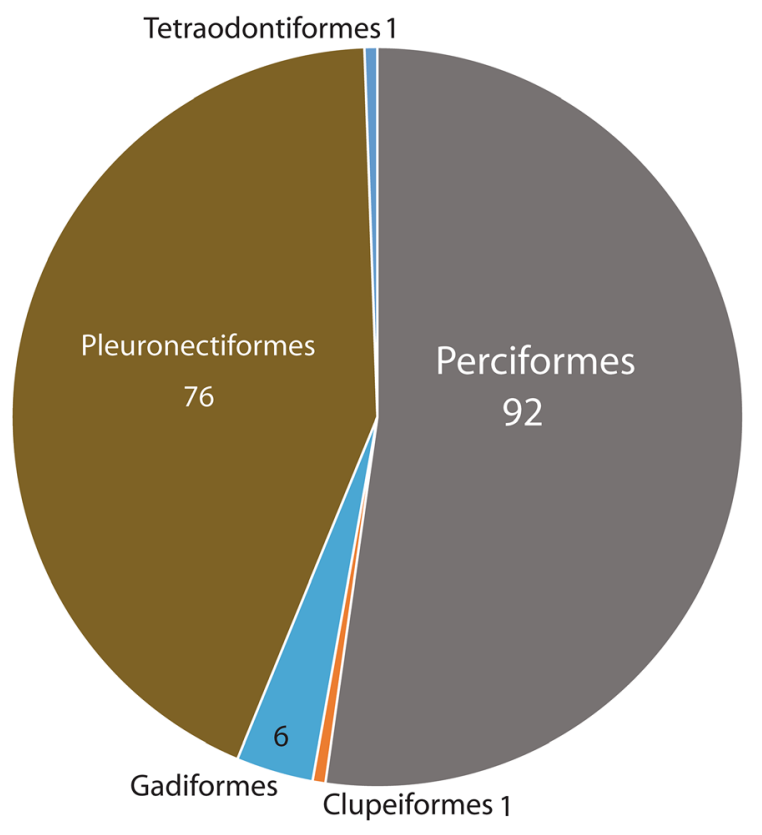

Fig. 8 Pie graph showing records of Steringotrema spp. from different host orders

considered a synonym of Steringotrema) from Pagrus caeruleostictus (Valenciennes) (as P. ehrenbergi Valenciennes) off Ghana (ecoregion 17, Gulf of Guinea). Not enough information is available to be confident that this was a correct identification. Steringotrema divergens (Rudolphi, 1809) has been reported in Pagellus bogaraveo (Brünnich) off Senegal (ecoregion 16, West African Transition) (Fischthal $\&$ Thomas, 1972; Vassiliadès, 1982). These are the only records of this species from sparids but there are no descriptions.

\section{Conclusion}

It is more satisfactory for phylogenies to include named and described species and, to this end, we have described here a species for which some molecular data are available. This species is not morphologically highly distinct, but it is from a rarely seen and difficult to obtain host. The only other report of a digenean from this species is that of the hemiurid Merlucciotrema praeclarum (Manter, 1934) by Bray (1996) from the same individual fish. This is a glimpse into the poorly known digenean fauna of the deep-sea, which is worthy of much more sustained study.

Acknowledgements We are greatly indebted to the staff and crew of the Research Vessel Discovery; to Imants 'Monty' Priede for allowing RAB to participate in his cruises; to Nigel Merrett for his expertise in fish identification and deep-sea 
trawling; and to many other colleagues and shipmates. We are also grateful to David Cooper who made the serial sections.

Funding The research for this paper did not receive any specific grant from funding agencies in the public, commercial or not-for-profit sectors.

\section{Compliance with ethical standards}

Conflict of interest The authors declare that they have no conflict of interest.

Ethical approval All applicable institutional, national and international guidelines for the care and use of animals were followed.

Open Access This article is licensed under a Creative Commons Attribution 4.0 International License, which permits use, sharing, adaptation, distribution and reproduction in any medium or format, as long as you give appropriate credit to the original author(s) and the source, provide a link to the Creative Commons licence, and indicate if changes were made. The images or other third party material in this article are included in the article's Creative Commons licence, unless indicated otherwise in a credit line to the material. If material is not included in the article's Creative Commons licence and your intended use is not permitted by statutory regulation or exceeds the permitted use, you will need to obtain permission directly from the copyright holder. To view a copy of this licence, visit http://creativecommons.org/licenses/by/4.0/.

\section{References}

Aleshkina, L. D., \& Gaevskaya, A. V. (1985). Trematodes of fishes of the Atlantic coast of Africa. Nauchnye Doklady Vysshei Shkoly Biologicheskie Nauki, 3, 35-40 (In Russian).

Antar, R., \& Gargouri, L. (2016). Morphology and molecular analysis of life-cycle stages of Proctoeces maculatus (Looss, 1901) (Digenea: Fellodistomidae) in the Bizerte Lagoon, Tunisia. Journal of Helminthology, 90, 726-736.

Arthur, J. R., \& Albert, E. (1994). A survey of the parasites of Greenland halibut (Reinhardtius hippoglossoides) caught off Atlantic Canada, with notes on their zoogeography in this fish. Canadian Journal of Zoology, 72, 765-778.

Bray, R. A. (1973). Some digenetic trematodes in fishes from the Bay of Biscay and nearby waters. Bulletin of the British Museum (Natural History) (Zoology Series), 26, 151-183.

Bray, R. A. (1995). Steringophorus Odhner, 1905 (Digenea: Fellodistomidae) in deep-sea fishes from the northeastern Atlantic, with the description of Steringophorus margolisi n. sp. Canadian Journal of Fisheries and Aquatic Science, 52, 71-77.

Bray, R. A. (1996). Merlucciotrema praeclarum (Manter, 1934) (Digenea: Hemiuridae) redescribed from myctophiform and gadiform fishes of the north Atlantic. Systematic Parasitology, 33, 135-141.
Bray, R. A. (2002). Family Fellodistomidae Nicoll, 1909. In: Gibson, D. I., Jones, A. \& Bray, R. A. (Eds), Keys to the Trematoda. Volume 1. Wallingford: CABI Publishing and The Natural History Museum. pp. 261-293.

Bray, R. A. (2004). The bathymetric distribution of the digenean parasites of deep-sea fishes. Folia Parasitologica, 51, 268-274.

Bray, R. A., \& Campbell, R. A. (1995). Fellodistomidae and Zoogonidae (Digenea) of deep-sea fishes of the NW Atlantic Ocean. Systematic Parasitology, 31, 201-213.

Bray, R. A., \& Gibson, D. I. (1980). The Fellodistomidae (Digenea) of fishes from the northeast Atlantic. Bulletin of the British Museum (Natural History), 37, 199-293.

Bray, R. A., \& Gibson, D. I. (1998). Further observations on the Digenea (Platyhelminthes) of deep-sea fishes in the northeastern Atlantic: Fellodistomidae and Zoogonidae. Acta Parasitologica, 43, 194-199.

Bray, R. A., \& Kuchta, R. (2006). Digeneans from deep-sea marine teleosts off the Outer Hebrides, Scotland, including the description of Brachyenteron helicoleni sp. nov. (Zoogonidae). Acta Parasitologica, 51, 169-175.

Bray, R. A., Littlewood, D. T. J., Herniou, E. A., Williams, B., \& Henderson, R. E. (1999). Digenean parasites of deep-sea teleosts: a review and case studies of intrageneric phylogenies. Parasitology, 119(Supplement), S125-S144.

Campbell, R. A. (1975). Abyssotrema pritchardae gen. et sp. n. (Digenea: Fellodistomidae) from the deep-sea fish, Alepocephalus agassizi Goode and Bean 1883. Journal of Parasitology, 62, 661-664.

Campbell, R. A. (1983). Parasitism in the deep-sea. In: Rowe, G. T. (Ed.), The Sea. Volume 8. New York: John Wiley and Sons, Inc., pp. 473-552.

Campbell, R. A., Haedrich, R. L., \& Munroe, T. A. (1980). Parasitism and ecological relationships among deep-sea benthic fishes. Marine Biology, 57, 301-313.

Chambers, C. (2008). Determining deep-sea fish community structure in the Arctic: Using species assemblages, stomach contents, parasite infracommunities and stable isotopes to evaluate trophic interactions. $\mathrm{PhD}$ Thesis, University of Manitoba, Winnipeg.

Constenla, M., Montero, F. E., Padrós, F., Cartes, J. E., Papiol, V., \& Carrassón, M. (2015). Annual variation of parasite communities of deep-sea macrourid fishes from the western Mediterranean Sea and their relationship with fish diet and histopathological alterations. Deep-Sea Research Part I: Oceanographic Research Papers, 104, 106-121.

Cribb, T. H., Miller, T. L., Bray, R. A., \& Cutmore, S. C. (2014). The sexual adult of Cercaria praecox Walker, 1971 (Digenea: Fellodistomidae), with the proposal of Oceroma n. g. Systematic Parasitology, 88, 1-10.

Cutmore, S. C., Bray, R. A., \& Cribb, T. H. (2018). Two new species of Bacciger Nicoll, 1914 (Trematoda: Faustulidae) in species of Herklotsichthys Whitley (Clupeidae) from Queensland waters. Systematic Parasitology, 95, 645-654.

Dallarés, S., Moyà-Alcover, C. M., Padrós, F., Cartes, J. E., Solé, M., Castañeda, C., et al. (2016). The parasite community of Phycis blennoides (Brünnich, 1768) from the Balearic Sea in relation to diet, biochemical markers, histopathology and environmental variables. Deep Sea Research. Part I: Oceanographic Research Papers, 118, 84-100. 
Fischthal, J. H., \& Thomas, J. D. (1968). Digenetic trematodes of some freshwater and marine fishes from Ghana. Proceedings of the Helminthological Society of Washington, $35,126-140$.

Fischthal, J. H., \& Thomas, J. D. (1972). Digenetic trematodes of marine fishes from Senegal. Bulletin de l'Institut Fondamental d'Afrique Noire, 34A, 292-322.

Froese, R., \& Pauly, D. (2019). FishBase. World Wide Web electronic publication. http://www.fishbase.org.

Gaevskaya, A. V., \& Aleshkina, L. D. (1983). New data on the trematodes from the fishes of Atlantic coast of Africa. Parazitologiya, 17, 12-17 (In Russian).

Gordeev, I., Sokolov, S., Bañón, R., Morales, X., \& Orlov, A. (2019). Parasites of the blue antimora, Antimora rostrata and slender codling, Halargyreus johnsonii (Gadiformes: Moridae), in the Northwestern Atlantic. Acta Parasitologica, 64, 489-500.

Harris, C. E., \& Dronen, N. O. (1999). Megenteron manteri n. sp. and Steringophorus sp. (Digenea: Fellodistomidae) from Monomitopus agassizzi (Ophidiidae) in the Gulf of Mexico. Systematic Parasitology, 44, 153-156.

Katoh, T. (2008). Recent developments in the MAFFT multiple sequence alignment program. Briefings in Bioinformatics, 9, 286-298.

Kellermanns, E., Klimpel, S., \& Palm, H. W. (2009). Parasite fauna of the Mediterranean grenadier Coryphaenoides mediterraneus (Giglioli, 1893) from the Mid-Atlantic Ridge (MAR). Acta Parasitologica, 54, 158-164.

Kuramochi, T. (2009). Digenean trematodes of fishes from deep-sea areas off the Pacific Coast of Northern Honshu, Japan. In: Fujita, T. (Ed.), Deep-sea Fauna and Pollutants off Pacific Coast of Northern Japan. National Museum of Nature and Science Monographs, 44, 25-37.

Kuramochi, T. (2014). Digenean trematodes of deep-sea fishes from the Sea of Japan. National Museum of Nature and Science Monographs, 44, 29-37.

Lebour, M. (1908). Fish trematodes of the Northumberland coast. Report on the Scientific Investigations, Northumberland Sea Fisheries Committee, 1907, 23-67.

Levinsen, G. M. R. (1881). Bidrag til Kundskab om Grønlands Trematodfauna. Oversigt over det Kongelige Danske Videnskabernes Selskabs Forhandlinger, 1, 52-84.

Linton, E. (1940). Trematodes from fishes mainly from the Woods Hole region, Massachusetts. Proceedings of the United States National Museum, 88, 1-172.

Littlewood, D. T. J., Bray, R. A., \& Waeschenbach, A. (2015). Phylogenetic patterns of diversity in cestodes and trematodes. In: Morand, S., Krasnov, B. \& Littlewood, D. T. J. (Eds.), Parasite diversity and diversification: Evolutionary ecology meets phylogenetics. Cambridge: Cambridge University Press, pp. 304-319.

Machida, M. (1988). Two species of trematodes from deep-sea fishes of northern Japan. Memoirs of the National Science Museum, Tokyo, 21, 107-112.

Maddison, W. P., \& Maddison, D. R. (2018). Mesquite: a modular system for evolutionary analysis. Version 3.51. http://www.mesquiteproject.org.

Manter, H. W. (1934). Some digenetic trematodes from deepwater fish of Tortugas, Florida. Papers from Tortugas Laboratory, 28, 257-345.
Manter, H. W. (1947). The digenetic trematodes of marine fishes of Tortugas, Florida. American Midland Naturalist, 38, 257-416.

Markle, D. F., \& Wenner, C. A. (1979). Evidence of demersal spawning in the mesopelagic zoarcid fish Melanostigma atlanticum with comments on demersal spawning in the alepocephalid fish Xenodermichthys copei. Copeia, 1979, 363-366.

Mateu, P., Montero, F. E., \& Carrasson, M. (2014). Geographical variation in metazoan parasites of the deep-sea fish Bathypterois mediterraneus Bauchot, 1962 (Osteichthyes: Ipnopidae) from the Western Mediterranean. Deep-Sea Research Part I: Oceanographic Research Papers, 87, 24-29.

Miller, M. J. (1941). A critical study of Stafford's report on "Trematodes of Canadian fishes" based on his trematode collection. Canadian Journal of Research, 19, 28-52.

Nacari, L. A., \& Oliva, M. E. (2016). Metazoan parasites of deep-sea fishes from the South Eastern Pacific: Exploring the role of ecology and host phylogeny. Deep-Sea Research Part I: Oceanographic Research Papers, 115, 123-130.

Noble, E. R., \& Orias, J. D. (1975). Parasitism in the bathypelagic fish, Melanostigma pammelas. International Journal for Parasitology, 5, 89-93.

Nylander, J. A. A. (2004). MrModeltest v2. Program distributed by the author. Evolutionary Biology Centre, Uppsala University, Sweden. https://www.abc.se/ nylander/.

Odhner, T. (1905). Die Trematoden des arktischen Gebietes. Fauna Arctica, 4, 289-374.

Oliva, M. E., Valdivia, I. M., Cárden, L., Muñoz, G., Escribano, R., \& George-Nascimento, M. (2018). A new species of Proctoeces and reinstatement of Proctoeces humboldti George-Nascimento \& Quiroga 1983 (Digenea: Fellodistomidae) based on molecular and morphological evidence. Parasitology International, 67, 159-169.

Olson, P. D., Cribb, T. H., Tkach, V. V., Bray, R. A., \& Littlewood, D. T. J. (2003). Phylogeny and classification of the Digenea (Platyhelminthes: Trematoda). International Journal for Parasitology, 33, 733-755.

Olsson, P. (1868). Entozoa, iakttagna hos Skandinaviska hafsfiskar. I. Platyhelminthes. Acta Universitatis Lundensis, 4, $1-64$.

Palm, H. W., \& Klimpel, S. (2008). Metazoan fish parasites of Macrourus berglax Lacépède, 1801 and other macrourids of the North Atlantic: Invasion of the deep sea from the continental shelf. Deep-Sea Research Part II: Topical Studies in Oceanography, 55, 236-242.

Parukhin, A. M., \& Lyadov, V. N. (1979). New genus and species of trematodes, fish parasites in the subantarctic zone of the Indian Ocean. Zoologicheskii Zhurnal, 58, 637-642 (In Russian).

Pérez-Ponce de León, G., Anglade, T., \& Randhawa, H. S. (2018). A new species of Steringotrema Odhner, 1911 (Trematoda: Fellodistomidae) from the New Zealand sole Peltorhamphus novaezeelandiae Gunther off Kaka point in the Catlins, South Island, New Zealand. Systematic Parasitology, 95, 213-222.

Polyanski, Y. I. (1955). [Studies on the parasitology of the fish in the northern seas of the USSR. Parasites of fish of the Barents Sea.] Trudy Zoologicheskogo Instituta, Leningrad, 
19, 5-170 (In Russian; English translation 1966 Israel Program for Scientific Translations).

Randall, J. E. (2007). Reef and shore fishes of the Hawaiian Islands (p. 546). Honolulu: Sea Grant College Program.

Reimer, L. W. (1985). Occultacetabulum dorsolineatum gen. et spec. nov. (Occultacetabulinae subfam. nov.), ein fellodistomider Digener aus einem Tiefseefisch der Straße von Mozambique. Angewandte Parasitologie, 26, 107-109.

Ronquist, F., Teslenko, M., van der Mark, P., Ayres, D. L., Darling, A., Höhna, S., et al. (2012). MrBayes 3.2: Efficient Bayesian phylogenetic inference and model choice across a large model space. Systematic Biology, 61, 539-542.

Shen, J. (1987). Digenetic trematodes of fishes from the East China Sea. III. Five new species of the families Bucephalidae, Fellodistomidae, Zoogonidae and Monorchiidae. Studia Marina Sinica, 28, 141-149.

Sokolov, S. G., \& Gordeev, I. I. (2015). New data on trematodes of Antarctic fish. Parazitologiya, 49, 12-26 (In Russian).

Spalding, M. D., Fox, H. E., Allen, G. R., Davidson, N., Ferdaña, Z. A., Finlayson, M., et al. (2007). Marine ecoregions of the world: A bioregionalization of coastal and shelf areas. Bioscience, 57, 573-583.

Strelkov, J. A. (1960). Endoparasitic worms of marine fishes of East Kamchatka. Trudy Zoologicheskogo Instituta, Leningrad, 28, 147-196 (In Russian).

Sun, D., Bray, R. A., Yong, R. Q., Cutmore, S. C., \& Cribb, T. H. (2014). Pseudobacciger cheneyae n. sp. (Digenea: Gymnophalloidea) from Weber's chromis (Chromis weberi Fowler \& Bean) (Perciformes: Pomacentridae) at Lizard Island, Great Barrier Reef, Australia. Systematic Parasitology, 88, 141-152.

Vassiliadès, G. (1982). Helminthes parasites des Poissons de mer des côtes du Sénégal. Bulletin de linstitute Fondamental d'Afrique Noire, 44, 78-99.
Wee, N. Q. X., Cribb, T. H., Bray, R. A., \& Cutmore, S. C. (2017a). Two known and one new species of Proctoeces from Australian teleosts: Variable host-specificity for closely related species identified through multi-locus molecular data. Parasitology International, 66, 16-26.

Wee, N. Q. X., Cutmore, S. C., Yong, R. Q. Y., \& Cribb, T. H. (2017b). Two new and one known species of Tergestia Stossich, 1899 (Trematoda: Fellodistomidae) with novel molecular characterisation for the genus. Systematic Parasitology, 94, 861-874.

Yamaguti, S. (1934). Studies on the helminth fauna of Japan. Part 2. Trematodes of fishes, I. Japanese Journal of Zoology, 5, 249-541.

Yamaguti, S. (1970). Digenetic trematodes of Hawaiian fishes (p. 436). Tokyo: Keigaku.

Zdzitowiecki, K. (1997). Digenea of fishes of the Weddell Sea: V. Two new species of the genus Steringophorus (Fellodistomidae). Acta Parasitologica, 42, 144-148.

Zdzitowiecki, K. (2002a). Occurrence of Digenea in fishes of the family Artedidraconidae in the Weddell Sea and other areas of Antarctica. Acta Parasitologica, 47, 306-309.

Zdzitowiecki, K. (2002b). Occurrence of Digenea in fishes of the family Bathydraconidae in the Weddell Sea and other areas of Antarctica. Acta Parasitologica, 47, 310-313.

Zubchenko, A. V. (1975). On the fauna of Macrouridae parasites in North Atlantic. Trudy Polyarnyi Nauchno-Issledovatelskii i Proektnyi Institut Morskogo Rybnogo Khozaistva $i$ Okeanografii im N.M. Knipovicha (PINRO), 35, 234-238 (In Russian).

Publisher's Note Springer Nature remains neutral with regard to jurisdictional claims in published maps and institutional affiliations. 